\title{
THE EFFECT OF THE GERMANIUM COMPLEX WITH NICOTINIC ACID ON OXIDATIVE MODIFICATION OF CARDIAC AND HEPATIC PROTEINS IN THE EXPERIMENTAL CHRONIC INTOXICATION WITH DOXORUBICIN IN RATS
}

\author{
V.P.Narokha
}

Bogomolets National Medical University

Key words: germanium; nicotinic acid; oxidative modification of proteins; myocardium; liver; doxorubicin

\begin{abstract}
Anthracycline antitumor antibiotics are widely used for the treatment of malignancies, but this group of drugs is known for their cytotoxic effects, especially cardiotoxicity. It has been proven that the adverse effect of anthracyclines on tissues is based on formation of the reactive oxygen species that enhance development of the oxidative stress. Among the body biomolecules proteins are the most sensitive to peroxidation; they can be the primary markers in determining this pathological process at the cellular level. To identify and prevent the oxidative stress is important for prevention of further tissue apoptosis and necrosis. The aim of the study was to investigate the effect of nicotinic acid and the complex compound of germanium with nicotinic acid (MIGU-1) on oxidative modification of myocardial and hepatic proteins in the experimental chronic intoxication with doxorubicin (CID) in rats. The pattern of modifications in the content of protein peroxidation products (neutral and basic 2,4-dinitrophenylhydrazine) in cardiomyocytes and hepatocytes in rats has been determined; it shows intensification of the oxidative stress in CID. Nicotinic acid in the dose of $10 \mathrm{mg} / \mathrm{kg}$ daily did not exhibit the hepatoprotective effect in CID. It has been proven that the use of the new complex compound of germanium with nicotinic acid in the dose of $10 \mathrm{mg} / \mathrm{kg}$ daily provide attenuation of protein peroxidation in rats' cardiomyocytes and hepatocytes in CID. The results obtained allow considering MIGU-1 as a drug with a possible cytoprotective activity, and its further study may be topical and prospective.
\end{abstract}

A dverse reactions to drug $A$ products take an important place in the structure of morbidity and mortality. Anticancer chemotherapy causes approximately $30 \%$ of all adverse reactions, cardiotoxicity being the most common one among them [6]. Formation of active oxygen species and their ability to bind to proteins of myocytes, which can significantly reduce the myocardial contractility, are major adverse effects of anthracyclines on the myocardium [11]. The study of protein oxidative modification (POM) is stipulated by the role of proteins in the cell and in the body as a whole. In addition, they are more susceptible to free radical oxidation, and their oxidation is the earliest and most stable indicator of the intensity of generation of active oxygen species which can be mediators of the cell damage in cardiovascular diseases $[4,9,15]$.

Considering the pathological role of the oxidative stress in development of diseases and new data on the antioxidant properties of nicotinic acid $[12,14]$ and efficacy of complex compounds of germanium with nicotinic acid [2-4] the aim of this work is to study POM in cardiomyocytes and hepatocytes under the effect of nicotinic acid and the complex compound of germanium with nicotinic acid (MIGU-1) synthesized for the first time in the laboratory of the Department of General Chemistry and Polymers of the I.I.Mechnikov Odessa National University under the supervision of professor I.Y.Seifullina on the model of chronic intoxication with doxorubicin (CID) in rats.

\section{Materials and Methods}

Experiments were carried out on Wistar albino rats weighing 180$220 \mathrm{~g}$ according to the European Union Directive 2009/10/63 EU on the protection of vertebrate animals used for experimental and other scientific purposes. All animals were divided into 4 groups of 10 animals each: 1 ) animals re- ceiving $0.9 \% \mathrm{NaCl}$ intramuscularly once a week for 5 weeks (group 1 , control); 2) animals receiving doxorubicin (DOX) intramuscularly in the dose of $5 \mathrm{mg} / \mathrm{kg}$ once a week for 5 weeks (group 2); 3) animals receiving DOX intramuscularly once a week for 5 weeks with concomitant intraperitoneal administration of nicotinic acid in the dose of $10 \mathrm{mg} / \mathrm{kg} /$ day (group 3); 4) animals receiving DOX intramuscularly once a week for 5 weeks with concomitant intraperitoneal administration of complex MIGU-1 in the dose of $10 \mathrm{mg} / \mathrm{kg} /$ day (group 4).

Evaluation of POM intensity was based on the reaction of protein carbonyl derivatives and Schiff bases with 2,4-dinitrophenylhydrazine (DNPH) with formation of neutral and basic 2,4-dinitrophenylhydrazones [1]. The optical density of the dinitrophenylhydrazones formed was recorded at the wavelengths of $346 \mathrm{~nm}$ and $370 \mathrm{~nm}$ (neutral aldehyde and ketone oxidative modification products) and at $430 \mathrm{~nm}$ and $530 \mathrm{~nm}$ (basic aldehyde and ketone oxidative modification products). The resulting values were calcu- 
The content of protein oxidative modification products in the heart muscle of rats, $\mathrm{CU} / \mathrm{mg}$ of protein $(\mathrm{M} \pm \mathrm{m}), \mathrm{n}=40$

\begin{tabular}{|c|c|c|c|c|}
\hline \multirow[b]{2}{*}{ Group } & \multicolumn{2}{|c|}{ Neutral products } & \multicolumn{2}{|c|}{ Basic products } \\
\hline & $\begin{array}{l}356 \mathrm{~nm}, \\
\text { aldehyde products }\end{array}$ & $\begin{array}{c}370 \mathrm{~nm}, \\
\text { ketone products }\end{array}$ & $\begin{array}{l}430 \mathrm{~nm} \text {, } \\
\text { aldehyde products }\end{array}$ & $\begin{array}{l}530 \mathrm{~nm} \text {, } \\
\text { ketone products }\end{array}$ \\
\hline Control & $0.65 \pm 0.04$ & $0.44 \pm 0.04$ & $0.32 \pm 0.03$ & $0.23 \pm 0.02$ \\
\hline CID & $0.67 \pm 0.06$ & $0.85 \pm 0.07^{*}$ & $0.74 \pm 0.06^{*}$ & $0.54 \pm 0.05^{*}$ \\
\hline CID + nicotinic acid 10 mg/kg & $0.66 \pm 0.05$ & $0.68 \pm 0.05^{* / \#}$ & $0.56 \pm 0.04^{* / \#}$ & $0.39 \pm 0.03^{* / \#}$ \\
\hline CID + MIGU-1 $10 \mathrm{mg} / \mathrm{kg}$ & $0.68 \pm 0.06$ & $0.59 \pm 0.04^{* / \#}$ & $0.49 \pm 0.05^{* / \#}$ & $0.32 \pm 0.03^{* / \#}$ \\
\hline
\end{tabular}

Note. * - comared to the control group $(p<0.05)$; \# - compared to the group with CID $(p<0.05)$.

lated per $1 \mathrm{mg}$ of the total protein using Lowry method [13].

Mean values were compared using either the t-test or MannWhitney U-test for non-parametric quantitative sampling. Excel and Statistica 6.0. programmes were used for statistical analysis. All results are presented as $\mathrm{M} \pm \mathrm{m}$ where $\mathrm{M}$ - is the mean value, $\mathrm{m}$ is the standard deviation, $\mathrm{p}-$ is the significance level ( $p \leq 0.05)$.

\section{Results and Discussion}

The increase in POM products in cardiomyocytes and hepatocytes in rats with CID indicates the activation of free radical processes and development of the oxidative stress.

The studies have shown that the content of neutral derivatives in rat hearts (registration at 356 and $370 \mathrm{~nm}$ ) is 2-fold higher than the content of alkaline derivatives (registration at 430 and $530 \mathrm{~nm}$ ) (Tab. 1). These results suggest that the secondary markers of the oxidative stress, neutral aldehyde products of $\mathrm{POM}$, dominate in the control group [7].

As a result of the studies conducted, a significant almost 2-fold increase in alkaline products was observed in cardiomyocytes in animals with CID. In these conditions formation of protein carbonyl derivatives may be due to oxidation of amino acid residues, which have alkaline properties.

The analysis of the POM product content in the liver showed a significant increase in the concentrations of the following compounds: the content of both neutral and basic aldehyde- and ketone-dinitrophenylhydrazones was significantly higher compared to the control group (Tab. 2).

The injection of nicotinic acid caused a reduction in POM products though the reduction in neutral and basic products was not statistically significant.

In the group of rats receiving a complex MIGU-1 a statistically significant reduction in neutral (34.9\% for aldehyde products and $28.6 \%$ for ketone products, p < 0.05$)$ and basic $(23.3 \%$ for aldehyde products and $29.1 \%$ for ketone products, $\mathrm{p}<0.05$ ) POM products was observed compared to the group of untreated animals with CID. At the same time, the levels of neutral and basic aldehyde products did not significantly differ from those in the control group, indicating a significant inhibition of free radical oxidation of the protein molecules when MIGU-1 was used in CID.

Despite numerous studies of causes of DOX cytotoxicity, especially on the myocardial tissue, this problem is not fully understood and is the subject of debate. It has been proven that DOX is able to enhance the oxidative stress [5], but there is an assumption that anthracycline antibiotics can inhibit the activity of alpha-actin, heavy and light chains of myosin, troponin-I and desmin [10].

Table 2

\section{The content of protein oxidative modification products in liver of rats, $\mathrm{CU} / \mathrm{mg}$ of protein $(\mathrm{M} \pm \mathrm{m}) \mathrm{n}=\mathbf{4 0}$}

\begin{tabular}{|l|c|c|c|c|}
\hline \multirow{2}{*}{\multicolumn{2}{c|}{ Group }} & \multicolumn{2}{|c|}{ Neutral products } & \multicolumn{2}{c|}{ Basic products } \\
\cline { 2 - 5 } & $\begin{array}{c}356 \mathrm{~nm}, \\
\text { aldehyde products }\end{array}$ & $\begin{array}{c}370 \mathrm{~nm}, \\
\text { ketone products }\end{array}$ & $\begin{array}{c}430 \mathrm{~nm}, \\
\text { aldehyde products }\end{array}$ & $\begin{array}{c}530 \mathrm{~nm}, \\
\text { ketone products }\end{array}$ \\
\hline Control & $0.92 \pm 0.08$ & $1.06 \pm 0.09$ & $0.84 \pm 0.07$ & $0.92 \pm 0.08$ \\
\hline CID & $1.49 \pm 0.13^{*}$ & $1.75 \pm 0.14^{*}$ & $1.46 \pm 0.11^{*}$ & $2.13 \pm 0.16^{*}$ \\
\hline CID +nicotinic acid 10 mg/kg & $1.25 \pm 0.11^{*}$ & $1.52 \pm 0.11^{*}$ & $1.27 \pm 0.11^{*}$ & $1.84 \pm 0.17^{*}$ \\
\hline CID +MIGU-1 10 mg/kg & $0.97 \pm 0.08^{\#}$ & $1.25 \pm 0.11^{\#}$ & $1.12 \pm 0.11^{\#}$ & $1.51 \pm 0.15^{* / \#}$ \\
\hline
\end{tabular}

Note. * - compared to the control group ( $p<0.05)$; \# - compared to the group with CID $(p<0.05)$. 
Decrease in the contractile protein expression and POM enhancement may be associated with the loss of the contractile function by myofibrils and the final myocardial dysfunction. According to some authors, there is also a correlation between liver diseases and the use of anthracycline antibiotics [8]. Since the liver performs many metabolic functions in the human body, its protection from toxic damage by anthracycline antibiotics is also important.

Therefore, the data on $\mathrm{POM}$ changes in the heart and liver in rats with CID after introduction of the complex of germanium with nicotinic acid (MIGU-1) indicate the probable cytoprotective effects of the complex studied, namely inhibition of free radical oxidative processes in cardiomyocytes and hepatocytes. It has been determined that the effectiveness of the new MIGU-1 combination is significantly superior to the effects of nicotinic acid, and it may indicate its probable cardioprotective and hepatoprotective effects and the prospect of further studies of its cytoprotective effects.

\section{CONCLUSIONS}

1. The results obtained indicate a deep oxidative damage of cardiomyocyte and hepatocyte proteins in chronic intoxication with doxorubicin in rats.

2. A new drug MIGU-1 (complex of germanium with nicotinic acid) in the dose of $10 \mathrm{mg} / \mathrm{kg}$ inhibits protein peroxidation processes in chronic intoxication with doxorubicin. It allows considering MIGU-1 as a drug with a possible cytoprotective activity, and its further study may be topical and prospective.

\title{
REFERENCES
}

1. Дубинина Е.Е., Бурмистров С.О., Ходов Д.А., Поротов Г.Е. // Вопросы мед. химии. - 1995. - Т. 41, №1. - C. 24-26.

2. Кресюн В.Й., Сейфулліна І.Й., Годован В.В. // Одеський мед. журн. - 2011. - №1 (123). - С. 31-35.

3. Лук'янчук В.Д., Сейфулліна І.Й., Літвиненко Д.Ф., Марцинко О.Е. // Фармакол. та лікарська токсикол. - 2016. - №1 (47). - С. 3-13.

4. Ніженковська І.В., Сейфулліна І.Й., Нароха В.П. та ін. // Фармакол. та лікарська токсикол. 2016. - №2 (48). - C. 74-79.

5. Barry E., Alvarez J.A., Scully R.E. et al. // Expert Opin Pharmacother. - 2007. - Vol. 8. - P. 1039-1058.

6. Cross M.J., Berridge B.R., Clements P.J.M. et al. // Br. J. Pharmacol. - 2015. - Vol. 172 (4). - P. 957-974.

7. Dalle-Donne I., Rossi R., Colombo R. et al. // Clin. Chem. - 2006. - Vol. 52 (4). - P. 601-623.

8. Damodar G., Smitha T., Gopinath S. et al. // Ann. Med. Health Sci. Res. - 2014. - Vol. 4 (1). - P. 74-79.

9. Dunlop R.A., Brunk U.T., Rodgers K.J. // Intern. Union of Biochemistry and Molecular Biol. - 2009. №61 (5). - P. 522-527.

10. Kim Y., Ma A., Kitta K. et al. // Mol. Pharmacol. - 2003. - Vol. 63. - P. 368-377.

11. Lewis W., Kleinerman J., Puszkin S. // Canc. Res. - 1982. - Vol. 50. - P. 547-553.

12. Li S.Q., Fenq L., Jianq W.D. et al. // Fish Shellfish Immunol. - 2016. - Vol. 55. - P. 212-222.

13. Lowry O.H., Rosebrough N.J., Farr A.L., Randal R.I. // J. Biol. Chem. - 1951. - Vol. 193, №1. - P. 265-275.

14. Silva de Paula E., Carneiro M.F., Grotto D. et al. // J. Toxicol. Environ. Health A. - 2016. - Vol. 79 (4). P. 174-183.

15. Stadtman E.R., Levine R.L. // Amino Acids. - 2003. - №25 (3-4). - P. 207-218.

\section{ВПЛИВ КОМПЛЕКСУ ГЕРМАНІЮ З НІКОТИНОВОЮ КИСЛОТОЮ НА ОКИСНУ МОДИФІКАЦІЮ БІЛКІВ СЕРЦЯ ТА ПЕЧІНКИ ЩУРІВ ПРИ ХРОНІЧНІЙ ІНТОКСИКАЦІЇ ДОКСОРУБІЦИНОМ \\ В.П.Нароха}

\section{Національний медичний університет ім. О.о.Богомольця}

Ключові слова: германій; нікотинова кислота; окисна модифікація білків; міокард; печінка; доксорубіцин

\begin{abstract}
Протипухлинні антибіотики з групи антрациклінів широко використовуються для лікування злоякісних новоутворень, однак препарати даної групи відомі своїм цитотоксичним ефектом, особливо розвитком кардіотоксичності. Доведено, що в основі ушкоджувальної дії антрациклінів на тканини лежить утворення активних форм кисню, які посилюють розвиток оксидативного стресу. Серед біомолекул організму найбільш чутливими до процесів перекисного окиснення є білки, які можуть бути первинним маркером у визначенні на клітинниму рівні даного патологічного процесу. Визначення та попередження розвитку оксидативного стресу $є$ важливим для запобігання подальшого апоптозу та некрозу тканин. Мета дослідження полягала у вивченні впливу нікотинової кислоти та комплексної сполуки германію з нікотиновою кислотою (МІГУ-1) на окисну модифікацію білків у міокарді та печінці щурів при експериментальній хронічній інтоксикації доксорубіцином. Встановлено характер змін вмісту продуктів перекисного окиснення білків (2,4-динітрофенілгідразонів нейтрального та основного характеру) в кардіоміоцитах та гепатоцитах щурів, який свідчить про посилення оксидативного стресу в умовах хронічної інтоксикацї̈ доксорубіцином. Нікотинова кислота в дозі 10 мг/кг щоденно не чинила
\end{abstract}


гепатопротекторного впливу в умовах ХІД. Доведено, що використання нової координаційної сполуки германію з нікотиновою кислотою в дозі 10 мг/кг щоденно сприяє затуханню процесу перекисного окиснення білків у кардіоміоцитах та гепатоцитах щурів на тлі ХІД. Отримані результати дозволяють розглядати МІГУ-1 в якості препарату з вірогідною цитопротекторною активністю, а його подальше вивчення актуальним та перспективним.

\section{ВЛИЯНИЕ КОМПЛЕКСА ГЕРМАНИЯ С НИКОТИНОВОЙ КИСЛОТОЙ НА ОКИСЛИТЕЛЬНУЮ МОДИФИКАЦИЮ БЕЛКОВ СЕРДЦА И ПЕЧЕНИ КРЫС ПРИ ХРОНИЧЕСКОЙ ИНТОКСИКАЦИИ ДОКСОРУБИЦИНОМ \\ В.П.Нароха}

Национальный медицинский университет им. А.А.Богомольца

Ключевые слова: германий; никотиновая кислота; окислительная модификация белков; миокард; печень; доксорубицин

Противоопухолевые антибиотики из группы антрациклинов широко используются для лечения злокачественных новообразований, однако препараты данной группы известны своим цитотоксическим эффектом, особенно развитием кардиотоксичности. Доказано, что в основе повреждающего действия антрациклинов на ткани лежит образование активных форм кислорода, которые усиливают развитие оксидативного стресса. Среди биомолекул организма наиболее чувствительными к процессам перекисного окисления являются белки, которые могут быть первичными маркерами в определении на клеточном уровне данного патологического процесса. Выявление и предупреждение развития оксидативного стресса являются важными для предотвращения последующего некроза и апоптоза тканей. Целью исследования было изучение влияния никотиновой кислоты и координационного соединения германия с никотиновой кислотой (МИГУ-1) на окислительную модификацию белков в миокарде и печени крыс при экспериментальной хронической интоксикации доксорубицином (ХИД). Установлен характер изменений содержания продуктов перекисного окисления белков (2,4-динитрофенилгидразонов нейтрального и основного характера) в кардиомиоцитах и гепатоцитах крыс, который указывает на усиление оксидативного стресса в условиях ХИД. Никотиновая кислота в дозе 10 мг/кг ежедневно не выявила гепатопротекторного влияния в условиях ХИД. Доказано. что использование нового координационного соединения германия с никотиновой кислотой в дозе 10 мг/кг ежедневно способствует затуханию процесса перекисного окисления белков в кардиомиоцитах и гепатоцитах на фоне ХИД. Полученные результаты позволяют рассматривать МИГУ-1 в качестве препарата с возможной цитопротекторной активностью, а его изучение актуальным и перспективным.

Address for correspondence:

Received in 21.03.2016

22, Pushkinska str., Kyiv, 01004.

Tel. (97) 644-84-51. E-mail: v.narokha@ukr.net.

Bogomolets National Medical University 